\title{
On the Application of Blended Learning in College English Teaching Guangcai Li
}

\author{
Jilin Agricultural University, Changchun, China \\ Email:372415102@qq.com
}

Keywords: Blended learning mode; Autonomous learning; Cooperative learning

\begin{abstract}
This paper is mainly designed to analyze the concept of the Blended Learning mode, and the application of blended learning in college English teaching from the aspects of the implementation of blended learning and the key factors of the success. It is pointed out that the Blended Learning mode can not only improve the level of college students' English, but also contribute to cultivating college students' autonomous learning and cooperative learning ability. At the same time, it is advocated that teachers practically play the leading role and students attach importance to the cognitive status during the course of blended learning with the assumption of the advantages of traditional teaching and network teaching integration.
\end{abstract}

\section{Introduction}

College English Teaching Requirements clearly pointed out that the new teaching model should live on the modern information technology, especially network technology, so that English teaching and learning can be free, to some extent, from restrictions of time and place, directed toward development of personality and self-learning [1]. The newly emerging teaching methods such as E-learning, MOOC and micro-courses are network-based and provide the necessary technical means for college English teaching to meet the above mentioned requirements. In addition, a number of teachers and students in traditional classrooms began to doubt the necessity of its existence. In recent years, more and more researchers have found that these advanced teaching methods can improve the students' self-inquiry learning ability and critical thinking level to a certain extent, but they have been equipped with some unavoidable shortcomings - which artificially keeps teachers' distance from students. Technology has huge potential to enrich and enhance the teaching of English. All the signs are that the use of computers, network communication and sophisticated video production facilities is set to expand. Both hardware and software are more readily available, but the potential can't be realized without adequate training for the staff involved. Especially in language teaching, online learning lacks the language practice unique to the traditional classroom and face-to-face communication between teachers and students, which is not conducive to the transmission and mastery of language knowledge. In view of this, people begin to explore balance and integration of the two teaching approaches-the traditional classroom teaching and online learning based on network technology. As a result, Blended Learning began to gradually enter into its practice in the college English teaching and the college English education sector.

\section{Literature Review}

In fact, the concept of widely respected Blended Learning is not new in the education sector in recent years. "the reason why it has been the focus and enjoying growing popularity is that it has been given a new connotation, therefore we might as well see it as a so-called new concept of 'old bottle of new wine'." [2]

Generally speaking, the concept of Blended Learning, which is being discussed in current Chinese education sector, was given by Kekang He, in 2003 in the seventh session of the global Chinese computer education application. He pointed out that the so-called Blended Learning is the combination of the advantages of traditional learning styles and of E-learning (ie, digital or networked learning). He added: "The new development of educational technology theory will stem 
from Blending Learning with the booming of new science and technology in computer". That is to say, it is considerably essential to play the guidance of teachers and inspire their main monitoring role of the teaching process, but also fully reflect their students' initiative, enthusiasm and creativity as a learning subject. Subsequently, Yueliang Zhou, Ronghuai Huang, Liu Wei and the like studied the relevant strategies of Blended Learning at the same time Guo Dan, Xiaogang Luo did some research on the effectiveness of the learning approach in colleges and universities. Although experts and scholars have different interpretations about the connotation of Blended Learning, it is generally accepted that the learning method or teaching method is a kind of online and offline teaching and learning in order to realize the integration of traditional classroom teaching and network teaching. By using the Blended Learning, students can not only receive the systematic knowledge from teachers, but also cultivate the ability of inquiry-based self-learning, and teachers can also maximize its guiding role through the network.

\section{The Implementation of the Blended Learning Mode}

The focus of Blended Learning is not on what things to be blended as teaching or learning materials or skills, but rather on how to mix all the online and traditional teaching materials with the expectation to optimize the learning outcomes and economic benefits; the work done in the course of blended learning is to provide appropriate learning materials to the suitable learners at the right time with the appropriate online and offline resources by adopting appropriate methods [3]. Kekang He believes that if a complete set of teaching links in the teaching mode of student-centered can be carried out, some factors must be taken into consideration such as the learning settings, the choices of learning resources and classroom discussions and so on and so forth, all of which are inseparable from the leading role of teachers. The reasonable educational notion can't simply make a choice between the two teaching modes of "teacher-centered" and "student-centered". The right way is to highlight the subject position of students as well as to give full play to the leading role of teachers, namely the combination of the two.

With the reflection on the effect of network teaching, the advantages of traditional teaching gradually return to the vision of the education sector. Therefore, Blended learning has been more acknowledged and attached more importance. After the notion and learning method of Blended Learning were introduced into China, the vast majority of blended learning processes in college English were almost the same, using the mode of "network self-access learning + classroom discussion+ after-class evaluation".

Before Class. Before-class activities should be considered as a process of self-access learning. It is important for teachers to begin a process of sensitization to self-access, including learner training, where many students feel most secure, i.e. in the classroom. By discussing and demonstrating self-access approaches to language learning, the teacher can encourage students to move toward independent learning which is believed to a reference point for all classroom procedure. In order for this to happen, Carvalho maintains there must be an interface between 'public domain' learning, that is, learning which is based on shared classroom activities and 'private domain' learning, that is, personal learning behavior. [4] In addition, he still holds that these two domains of learning should be integrated, which means the necessity of blended learning of self-access learning and classroom based learning.

Before implementing the Blended Learning mode, the teacher should know of the students' learning styles, that is, their likes and dislikes which are unconscious approaches to language learning which, when recognized, can help learner become aware of their language learning potential [5]. After discussing with learners their learning styles and how they might affect the way they learn a language, teachers can begin to explore specific learning strategies with them. A learning strategy is a specific mental procedure for gathering, processing, associating, categorizing, rehearsing and retrieving information or patterned skills.

Acting on the Blended Learning mode, before class, the English teacher should follow the teaching plan, inform students of their following tasks, provide them with some online or offline teaching materials including the micro-video, teaching materials CD, college English self-access 
learning platform and open network space through QQ, We-Chat, micro-blogging or public e-mail with the help of the Internet. The students should collect and organize background information related to the theme of the text, analyze the text structure and vocabulary phrase usages, and then complete after-class exercises and make some preparations for other traditional classroom teaching contents. According to the pre-assigned group for collaborative learning and inquiry learning, they solve the tough problems encountered in the process of self-learning through the chat tool group discussion.

Through the reorganization and inversion of the traditional classroom process, the traditional classroom teaching content is transferred to the extracurricular, so that students will be equipped with the ability to flexibly choose the time for learning and learning contents suitable for their own knowledge level according to their actual situation. At the same time, students can communicate with classmates, team members and teachers through the above network tools. This learning process can reflect the students' subjectivity to great extent, which can improve their positive initiative and their learning efficiency.

Class Activities. By helping students to think about what they are doing in the language classroom in advance, teachers encourage them to become more involved in classroom activities. Therefore, teachers' responsibilities go beyond that of being informers, organizers, monitors and evaluators; they also become stimulators of thinking about ways to learn and ways to apply learning. [6] If some problems can't be resolved by the independent thinking and discussion of the group members, such a problem can be brought to the classroom. At the beginning of classroom teaching, teachers can summarize the problems raised by students in the process of pre-class self-learning, which is conducive to cultivating critical thinking ability. On this basis, teachers put forward targeted and feasible inquiry requirements allowing the study groups to discuss in accordance with their own classroom design.

The teacher is better to require the group leaders chosen from the students to organize and stimulate individuals to actively participate in assigned tasks from their teacher by project work which can encourage cooperation between peers. Following that, the teacher can tackle the difficult problems from the group by demonstrating teaching video, making presentations or lectures and something like that, and answer questions from the team members and present the results of inquiry learning through PPT, speech or live performance in order to for all students to exchange and share the common results. During the process, teachers should supervise, guide and make some comment on students' inquiry learning process, answer students' difficult questions in time, and make suggestions on students' learning strategies.

After Class. Once teachers employ the Blended Learning mode as a main teaching approach, they have to regard self-access as part of teaching planning; once learners have begun using self-access as part of their language learning experience, they must be encouraged to engage in a process of reflection on their learning.

Evaluation and reflection have filled a special place in Blended Learning mode. Compared with the relatively controllable traditional classroom teaching, the Blended Learning teaching shifts the main body from the teachers to the students. Therefore, the teaching effect is unpredictable for the teachers. Although the teachers will fully supervise every student in the classroom teaching, guiding students' learning process, they lack objective understanding and evaluation on the individual learning effect because of big classes in colleges and universities. A major belief among students is that it is their teacher's responsibility to assess and take responsibility for their language learning. It's suggested that learners should establish learner profiles to encourage learners to change their beliefs.[7] Teachers need to provide students with ongoing opportunities to reflect upon and articulate what it is they are learning, why they are learning it, and how the learning is helping them to acquire new information strategies and skills. On this basis, students are encouraged to keep a learner $\log$ or diary which can make a factual account of what happened. A diary is a personal account and may include feelings and emotions. The students can choose to use their logs as part of their portfolio assessment. 
Blended Learning mode adopts multi-dimensional evaluation mechanism which combines process evaluation with result evaluation. It requires that the students make evaluation, such as self-evaluation, team members' and teachers' assessment of each student's knowledge, small group participation and task completion through the network communication platform and survey tools. The results will provide feedback to teachers and students to help them reflect on the teaching and learning process. This evaluation mechanism will be of great help for teachers to sum up the teaching planning and accumulate teaching experience by using the mode of Blended Learning.

Reflection is a crucial element in the Blended Learning mode. By keeping a written account of their work and their reflection on it, learners gain deeper insights of their learning processes and preferred styles with the combination of abundant online and offline resources. In the long run the students will head toward a more autonomous way of learning.

\section{The Key Factors in the Success of the Blended Learning Mode}

From the perspective of the past blended learning effect, although students watched the teacher's elaborate and vivid image of the micro-video, organized the classroom discussion and supervised the students' performance, they did not achieve the desired learning effect. The language-learning outcomes seem not to be good. The motivation of the students to take part in lessons was also poor. Apart from the lack of support from hardware and educational technology, the success of blended learning also needs the real role shift for teachers and students and organize effective dialogues among students, otherwise the effect will be unsatisfactory. It was therefore decided to encourage students to take more responsibility for their learning, in particular the planning, monitoring and evaluation of their progress. The teachers continued to teach the core units of the courses, but the students are asked to use the plentiful online and offline resources to extend and consolidate their learning in ways they found useful and interesting.

In the blended learning, college English teachers should provide students with enough opportunities and plenty of time to allow them to communicate and practice the target language, which is mainly different from the traditional college English classroom. But that is not to say that teachers in the classroom teaching will be able to act as a bystander, and not participate in students' inquiry learning activities. Although blended learning can greatly improve students' ability of autonomous learning to a certain extent, the mode has some requirements for their initiative, namely students must be possessed with basic qualities like self-discipline and self-awareness in classroom communication, otherwise communicative activities would become chaotic in the class. [8] The Blended Learning mode requires teachers to give full play to their leading role in this process. Teachers must monitor the students' learning process from time to time. When students encounter problems that can't be dealt with they point out the direction of exploration in a timely manner to help students successfully out of trouble. In addition, teachers should direct students to actively evaluate and reflect, better their learning strategies and improve learning outcomes.

Students should cultivate good habits of self-learning under the needs of self-development and realize the goal of shift from passive recipients of traditional classroom knowledge to active constructors of blended learning.

The students are allowed the freedom to work on tasks that interest them. However, it soon becomes clear that they need support to guide them through the tasks and to operate within the framework of the target lessons. In essence, the students have to learn how to learn first before they could work independently of the teacher to make good preparations for the coming class, which requires a degree of personal competence. In fact, students could not learn and interact among them randomly and casually in the process of blended learning, but they should engage in cooperative organized learning with special target. On the other hand, In order to avoid individual students' personal performance in the classroom discussion, each student should be required to take the initiative to cooperate with each other to create a language learning environment suitable for language practice, carry out effective classroom interactive activities, and collaborate to find the themes of inquiry learning, learning strategies and solutions. Only in this way can blended learning really become the best place to complete the process of second language acquisition. 


\section{The Significance of Blended Learning mode in College English Teaching}

The Blended Learning mode is helpful for teachers to play a leading role in classroom teaching, and for students to initiatively make more choices in English learning. The teachers can monitor the students' learning process in the network by means of the teacher-led activities. During the course of network learning, students will be capable of utilizing more diversified learning resources and interactive tools to enhance their own spirit of inquiry and research capabilities. Most important of all, with the continuous play and strengthening of the students' main role, the students' innovative ability will be gradually strengthened, while autonomous learning is more conducive to student's cultivation of self-management and self-development.

Depending on the support of the network platform, the Blended Learning mode can extend the scope of time and space for students' learning. In terms of space, the teachers can provide learning resources for students on the network teaching platform to self-study before class. After class, students can expand their learning space relying on the network platform so that the classroom teaching will be extended to the online teaching which can greatly extend the space of "poor" classroom. As far as time is concerned, students will have more self-access learning time in the blended learning, not just limiting learning practice within 45 minutes of traditional classroom teaching. In this case, the Blended Learning mode can be a good solution to the traditional teaching deficiency of limited school hours, limited learning resources and limited issues. Moreover, teachers can also use the network teaching platform to monitor students' learning process, so that teachers can gain a good command of the students' learning effect more comprehensively and objectively.

The blended learning can create a real language atmosphere which is crucial to second language acquisition. We have seen a lot of similar experiences that some students' ability is very common in acquiring language knowledge, but if they go abroad to study in English-speaking countries for some time, his English ability has a qualitative improvement in a very short period of time. This is because the students are there in the English-speaking countries and their English ability will be greatly improved, which is lacking in the traditional college English classroom. Due to the constraints of classroom space and time, students can not feel the real language exchange atmosphere when they communicate with teachers face to face. What's more, they can't perceive the role and significance of the language in the real life of the students so that they will lose interest and enthusiasm in learning English. While the students are in the Blended Learning mode, students will have more opportunities to use the network and multimedia resources to learn, because the network can create a virtual language for students with more opportunities to use English to communicate. Finally that will greatly stimulate students' interest in learning, allowing students a chance to experience the success of language learning.

\section{Conclusion}

The Blended Learning mode gains more popularity with the easy access to abundant online resources. With the network platform, the students gradually find it very convenient to learn a language. The relationship between teachers and students will be influenced and their role shift will emerge with diverse forms. In the blended learning, students can improve their autonomous learning ability and critical thinking ability through pre-class online learning. Teachers can effectively supervise and guide the students' inquiry learning process and play leading role in their teaching. The students can be treated as the main body during the implementing of the mode. This fusion can not only inherit and carry forward the advantages of knowledge transmission of traditional English classroom teaching, but also meet the requirements of the students' personality through the modern educational technology. The students' language knowledge and skills can be really put into practice through classroom discussion and exchange, thus greatly improving their learning initiative and efficiency. However, it remains to be verified whether students' existing levels of autonomous learning and critical thinking can help them improve their learning outcomes. Meanwhile, College English teachers should continue to study and practice this teaching or learning 
model in college English teaching and reform, making it geared to China's college English teaching in the Internet age.

\section{References}

[1] P.F. Xu, Talking about the College English Interactive Teaching Mode Based on the Network Environment. Science and Technology Guide (electronic version) (2013)

[2] T.E. Huang , \&, L.G. Li, Based on the Blackboard Network Teaching Platform of College English Mixed Teaching Model. Education Theory and Practice, (2014), 6, 55-57.

[3] Y.Q. Wang, Depth Teaching: The Construction of High Quality and Efficient Classroom Method. Shanghai: East China Normal University Press (2012)

[4] G. Yang, \& R. Zhao, Ubiquitous Learning Environment in the Construction of College English Oral Language Courses. Modern Educational Technology (2013) 6, 67 -70,75.

[5] Williams, M, Burden R.L, Psychology for Language Teachers: a Social Constructivist Approach. Beijing: Foreign Language Teaching and Research Press (2000)

[6] Y. L. Chai, A Survey of English Listening and Speaking Learning Needs by Non - English Majors Based on Micro-letter. Foreign language teaching (2013) 5, 34 - 39.

[7] Carvalho, D.. Self-access: Appropriate Materials. Manchester: British Council (1993)

[8] National Education Technology Plan 2010. [DB/OL].2010-11-9.[2014-4-10]. http: //www. ed.gov/ technology/ netp-2010. 